\title{
Attempting Institutional Change: Swedish Apprenticeship, 1890-1917
}

\author{
Sandra Hellstrand
}

\begin{abstract}
Sweden never got an apprentice law after apprenticeship was de-regulated in 1864 . This has been attributed to unified opposition to legislation from industry employers and trade unions, with the craft employers as the only advocates. Analysing the pattern of agreement and disagreement in the political struggle over apprenticeship in the Swedish case in 1890-1917, it is clear that opposition was not that uniform, nor was the support from the craft employers that undivided. This article makes use of Kathleen Thelen's model of institutional change in order to shed new light on the developments in Sweden. The model states that any apprentice law requires a coalition of two or more out of the state, the crafts and the metalworking industries - divided into employers and workers. Legislation, in turn, is a near requirement for the survival of strong apprenticeship. In this article the Swedish case will be discussed in relation to two of Thelen's cases, Germany and Great Britain. In Germany an apprentice law was passed in 1897, while in Great Britain no modern apprentice law was ever passed. Similarities can be found between both of these cases and the Swedish case.
\end{abstract}

Keywords • apprenticeship, training, skill, institutions, Sweden

\section{Introduction}

In the mid-1800s, freedom of trade was spreading throughout Europe, making entry into the crafts much easier than during the guild period. The concomitant de-regulation of apprenticeship caused dissatisfaction among European craft employers. Meanwhile, industry became a new training arena and new unions and employer organisations emerged with stakes in apprenticeship. In some countries, the state took an active interest in training and re-introduced legislation on apprenticeship. ${ }^{1}$

In a study of the institutions of modern, post-guild, apprenticeship in Germany, Great Britain, the United States and Japan, the political scientist Kathleen Thelen argues that all systematic regulation of apprenticeship must be supported by a coalition of actors. In Thelen's view the potential candidates for forming a coalition in the area of apprentice training are employer organisations, trade unions and the state. However, not all employer organisations or unions are equally likely to be interest-

1 Anders Nilsson, "From One Model to the Other: Swedish Vocational Education and Training in the Twentieth Century," in Utbildningens sociala och kulturella historia: Meddelanden från den fjärde nordiska utbildningshistoriska konferensen, ed. Esbjörn Larsson and Johannes Westberg (Uppsala: SEC, Uppsala University, 2010), 87; Kathleen Thelen, How Institutions Evolve: The Political Economy of Skills in Germany, Britain, the United States, and Japan (Cambridge: Cambridge University Press, 2004), xii-xiii, 6, 31-33, 46, 106-7, 111-13, 116, 278, 286-89, 294-95; Lars Pettersson, Är Danmark bättre än Sverige? Om dansk och svensk yrkesutbildning sedan industrialiseringen (Malmö: Øi förlag, 2006), 12-14.

Sandra Hellstrand is a Doctoral Student at the Department of Economic History, Stockholm University, Sweden.

Email: sandra.hellstrand@ekohist.su.se 
ed in apprenticeship regulation, the level of knowledge-intensity of the production is often a decisive factor. Hence, employer and worker organisation within knowledge-intensive sectors, such as the crafts and the metalworking industries, are more likely to be interested in legal regulation of apprenticeship, while employers and workers within less skill-dependent industries are more likely to be disinterested. While coalitions support apprentice regulation, class conflict undermines it. Thelen avoids the power resources perspective, arguing against the idea that institutions always adjust to changes in power, instead she argues that purposive actors create institutions, but a gap may emerge between their intentions and the actual effects of the institution. Furthermore, power is less tangible and harder to study than interests, which may be explored in an analysis of political demands. Consequently, Thelen focuses on the latter. ${ }^{2}$

In Germany, a coalition between the state and the craft employers underlay the 1897 apprentice law. The 1897 reform gave craft employers the right to certify skills and created a conflict between craft and industry employers. The industry employers sought the same certification rights as the craft employer. Later, the law was expanded to include industry employers and workers' representatives. In Thelen's terms, the training was contested between craft and industry employers, meaning that there was conflict and rivalry between these two actors over how apprenticeship ought to be organised and controlled. In Great Britain, the conflict over training was between employers and workers. Trade-based craft unions tried to control training in order to limit the number of apprentices, thereby limiting the supply of skilled labour within their crafts, which in turn would strengthen the unions' position in collective bargaining. In the end the employers wrestled the control of training from the craft unions, defeating the unions' attempt at limiting the supply of skilled labour, but by then apprenticeship had become an area of class conflict. There was no coalition and no law. ${ }^{3}$ In existing research, the Swedish industry employers and unions have been seen as opposed to apprenticeship legislation, while the craft employers were the only advocates. In this article, I argue that this image needs to be nuanced. I will explore the political demands of the Swedish actors involved in the conflict surrounding apprenticeship, between 1890 and 1917. The analysis will reveal the areas of agreement and disagreement between the actors.

The aim of the study is to contribute to the Swedish history of vocational training in a European perspective by nuancing the picture of why Sweden did not get an apprentice law during the investigated period. The study will answer these questions: To what degree was there agreement between the actors? What were the implications for institutional change in general and an apprentice law in particular? How does the outcome compare to the developments in Germany and Great Britain regarding coalition building?

Vocational training during the era of the Swedish guilds consisted of between three and six years of training that ended with a mandatory test. An additional test

2 Thelen (2004), xii-xiii, 6, 31-33, 46, 106-7, 111-13, 116, 278, 286-89, 294-95; Pepper D. Culpepper and Kathleen Thelen, "Institutions and Collective Actors in the Provision of Training: Historical and Cross-National Comparisons," in Skill Formation: Interdisciplinary and Cross-National Perspectives, ed. Karl Ulrich Mayer and Heike Solga (Cambridge: Cambridge University Press, 2008), 25-26, 29, 43.

3 Thelen (2004), 39-40, 43-47. 
was thereafter required to become a master. In 1846, local mandatory associations of all craft producers, regardless of trade, replaced the guilds. The associations oversaw the still mandatory master examinations and the now voluntary apprentice test. In 1864, freedom of trade was introduced. The employer, the apprentice and his/her legal guardian could now freely agree on the terms of training. The associations, unlike the guilds, were allowed to remain in voluntary form. ${ }^{4}$

The Swedish craft employers wanted an apprentice law and the period 1890-1917 is key to understanding why no law was passed. The craft employers' objections to de-regulated training were not new, but in the 1890s they got the issue onto the political agenda and into parliament. Meanwhile, unions and employer organisations emerged. Throughout the period there was a transition in the labour market from a patriarchal system to a system of collective bargaining, with both co-existing for a long time. Training was sometimes covered by collective bargaining. ${ }^{5}$

Apprenticeship is a long-term cost-sharing agreement, with both educational and economic elements. The employer agrees to train the apprentice in a broad set of skills and the apprentice agrees to work for a low training wage for an extended period of time. Apprenticeships, obviously, involves risks. Employers can, for example, exploit apprentices as a cheap labour, demanding more work at the expense of training. At the end of the training period, when the gap is widest between their training wages and the wages of skilled workers, apprentices may also leave for a job with higher wages. Other employers may also poach half-trained apprentices. Certification, tests, formal contracts and poaching bans can minimise cheating and can operate through norms, formal contracts or collective bargaining, but the most effective way to control cheating is by law. ${ }^{6}$

Specific ways of organising apprenticeship may benefit one or both of the parties. Long indentures (lärlingskontrakt) mainly benefit the employers. They have longer to recuperate their training investment and get secure access to cheap labour. Tradebased craft unions may nevertheless push for long indentures, as it limits competition in the labour market and consequently strengthens the unions' positions. On the other hand, unions may seek shorter training periods as a way to limit the risk of apprentices being exploited as a source of cheap labour. Regulation of the number of apprentices can have both of these favourable effects for the unions, simultaneously limiting competition in the labour market and making it harder to exploit apprentice. Tests can benefit both parties and make it harder to cheat, resulting in a qualification for the worker and functioning as a control of the training offered by the employer. Tests also make it easier for employers to recruit apprentices. It is sometimes obvious that a particular way of organising training benefits either the employers or the workers. However, in many cases, the question of who benefits is dependent upon the historically specific situation and strategies of the actors. By studying the political demands of the actors I will reveal these historically specific aspects of the Swedish apprentice debate.

4 Folke Lindberg, Hantverk och skråväsen under medeltid och äldre vasatid (Stockholm: Prisma, 1964), 78-80, 82-83, 87; Tom Söderberg, Hantverkarna i brytningstid: 1820-1870 (Stockholm: Vasatryckeriet, 1955), 88-100.

5 Christer Lundh, Spelets regler: Institutioner och lönebildning på den svenska arbetsmarknaden 18502010 (Stockholm: SNS förlag, 2010), 81-2.

6 Nilsson (2010), 87; Thelen (2004), 17-19, 46, 70-71, 106-7, 111-13, 116. 
From an institutional perspective 1890-1917 was a time period of small, partly incremental, changes concerning the regulation of apprenticeship, but relatively intense debate of more ambitious institutional changes, mainly in the shape of legal regulation. In 1890, Swedish apprenticeship was supported by norms and the craft associations' voluntary tests. In 1917, three official enquiries had failed to produce an apprentice law. The number of tests was falling. Regulation of training through collective bargaining had emerged. Limited state financial support had been instituted. Very soon afterwards, in 1918, a system of part-time theoretical vocational schools was introduced. The schools were meant to complement, not replace, apprenticeship. This study covers the attempts at institutional change in the area of apprentice training, the support and opposition to the different ways of regulating training and the outcome of the political struggle over apprenticeship.

\section{Method and sources}

My analysis in this article is inspired by Thelen's approach. Thelen studied post-guild apprenticeship in Germany, Great Britain, the United States and Japan. The broader aim of her work was to understand the emergence and evolution of the institutions that regulate skill production. In three of the cases, Thelen focused on the end of the nineteenth century and the beginning of the twentieth, while in the German case her time period extended further towards the present.

My study differs from Thelen's in a number of ways. Her account is based largely on secondary literature, while this study is mainly based on primary sources that are subjected to qualitative text analysis. This article covers a shorter time period and lacks the comparative scope of Thelen's work.

The disadvantage of the more limited scope of this article is that the results do not lend themselves to the creation of an explanatory model in the same way that Thelen's wider study did, though the addition of the Swedish case can illustrate the variations of the political dynamics in the early years of modern skill regimes. On the other hand, the closer focus on the Swedish case as well as the use of primary sources and qualitative text analysis enables a closer look at the argumentation of the actors and greater focus on agreement and disagreement as underlying factors in coalition building. This, in turn, brings to light the role of the specific content of the proposed solutions to the problems plaguing apprenticeship. ${ }^{7}$

The sources utilised in this study are parliamentary materials, official enquiries and consultations. Some of these source materials have certainly been neglected. During the investigated time period a number of specific proposals and drafts of apprentice legislation were presented. The first was an 1893 craft employer draft. Later drafts, proposals and enquiry reports were produced by state committees and published in 1900, 1909, 1910, 1911 and 1913. Here, the 1911 report is treated together with the $1913 \mathrm{draft}$, for which it mostly laid down the groundwork. The first official state enquiry, from 1900, has previously received little attention. The report was neither published, nor archived, by the state, but a copy in full was published as an offprint of Handtverks- och industri-tidning. ${ }^{8}$

The parliamentary materials originate from an 1895 decision to investigate the

7 Thelen (2004), 5, 31-33.

8 Lärlingsfrågan inför regeringen (Stockholm: Iduns kungliga boktryckeri, 1900). 
question of apprentice legislation and a 1917 decision to institute limited state financial support for apprentice training. The relatively heated 1895 debate in the second chamber of parliament has been under-utilised in previous research.

The craft employers, the main advocates of legislation, are studied in more depth through periodicals and minutes from annual meetings. This allows me to follow the debate continuously, but it is important to keep in mind that the analysis of the craft employers is more thoroughly supported than that of the other actors. In particular, the sources produced by the craft employers include an inside view that can reveal issues of cohesion and strategy, while for the other actors the sources are limited to external communications.

Unions and industry employers are covered through consultations before the 1900 report and after the 1909 and 1913 reports. This material does not, in general, allow me to follow the same organisation over time. For the 1900 consultation we do not have access to a list of replies and there is not much overlap between the replies in the 1909 and 1913 consultations. Original replies are available only for the 1913 consultation; the other sources are summaries. In 1900, the large, national organisations for industry employers did not exist, and it is likely that no effort was made to include industry; the law was meant for the crafts only, as was the 1909 draft. Apart from mechanical engineering, the only replies from industry employers are from the 1913 consultation.

\section{Previous research}

Previous studies of Swedish apprenticeship have often covered both education and training over long time periods. The brunt of research has been devoted to later periods; a common starting point is the 1918 and 1921 vocational school reforms. The disproportionate attention paid to schools, even when apprenticeship was more common, may be connected to the dominance of schools from the 1950 s onwards. ${ }^{9}$ This study of the period 1890-1917 consequently covers a neglected period of Swedish apprenticeship.

Nevertheless, some blanks of this research field have already been filled. The economic historian Anders Nilsson has, for example estimated the number of apprentices between 1850 and 1910. The economic historian Fay Lundh Nilsson has studied the value placed on training and the proportion of apprentices in the engineering industry around 1900. The historian Tom Söderberg offers some description of apprenticeship at the turn of the century and, while writing the history of the craft sector in general and Sveriges handtverksorganisation in particular, he touches on the craft employers' stances in the politics of skill formation. ${ }^{10}$

9 Peter Håkansson and Anders Nilsson, ed., Yrkesutbildningens formering i Sverige 1940-1975 (Lund: Nordic Academic Press, 2013); Jonas Olofsson, Svensk yrkesutbildning: Vägval i internationell belysning (Stockholm: SNS förlag, 2005); Jonas Olofsson and Eskil Wadensjö, Lärlingsutbildning: Ett återkommande bekymmer eller en oprövad möjlighet? (Stockholm: Finansdepartementet, Regeringskansliet, 2006); Pettersson (2006); Lisbeth Lundahl, Efter svensk modell: LO, SAF och utbildningspolitiken 1944-90 (Umeå: Boréa, 1997).

10 Anders Nilsson, Yrkesutbildningen i Sverige 1850-1910 (Uppsala: Föreningen för svensk undervisningshistoria, 2008); Fay Lundh Nilsson, Lönande lärande: Teknologisk förändring, yrkesskicklighet och lön i svensk verkstadsindustri omkring 1900 (Stockholm: Almqvist \& Wiksell International, 2007), 79, 96, 101-5, 144-46, 152, 159, 183-84, 187, 192-93; Tom Söderberg, Hantverkarna i genombrottsskedet 1870-1920 (Stockholm: Vasatryckeriet, 1965). 
This study is not the first to cover institutional change regarding apprenticeship, though it is the first to cover the time period between 1890 and 1917 in depth. Nilsson argues that Sweden has changed skill regimes repeatedly. Nilsson utilises a set of ideal types to describe these shifts. The British ideal type is a liberal, market-based system with no apprentice law and no national system of vocational schools. The French ideal type is a statist system, heavily dependent on vocational schools, while the German ideal type is a system of strong apprenticeship supported by apprentice legislation combined with vocational schools. Nilsson argues that the Swedish system before 1918 was similar to the British, unregulated model because craft and industry employers were unable to combine their interests. However, Nilsson only hints at the reasons behind this inability to agree, stating that the craft employers were worried about apprentice recruitment and the unions were suspicious of apprenticeship. The historian Ingrid Lindell, while studying vocational school reforms, mentions that the 1913 apprentice law failed due to widespread disagreement in the consultation. Lindell never clarifies who was disagreeing with whom, or what the disagreement consisted of. ${ }^{11}$

The economic historian Lars Pettersson uses the concept 'production regimes' to explain the divergence of the Swedish and Danish systems, with smaller, craft firms in Denmark and larger, industrial ones in Sweden. In his view, Swedish industry had the power to shape the skill system and the unions were united with them in opposing an apprentice law. The opinions of those employer and worker organisations that were at times more positive towards apprentice legislation have been left out by Pettersson. The political scientists Michael Dobbins and Marius R. Busemeyer, analysing the same two cases, agree and add that the Swedish craft sector was weak and unable to build on its guild traditions or to offer a viable alternative to mass production. In their description of the time around the turn of the century they mention the vocational schools, but ignore training. ${ }^{12}$

Other scholars have studied the turn of the century politics of vocational schools. A diverse set of lower technical evening and Sunday schools that supplied basic theoretical education emerged in the nineteenth century. In 1918 a reform created a national system of part-time, theoretical vocational schools as a complement to training. Lindell argues that the aim of the 1918 reform was to increase skills and improve worker discipline. The reform was supported by a coalition of craft and industry employers, teachers, the state, conservatives, liberals and social democrats. The educational researcher Anders Hedman adds that industry employers were only briefly interested in skills in the 1910s, while craft employers had a continuous interest in skills. The unions were disinterested in the vocational schools. A 1921 reform added full-time workshop schools that replaced apprenticeships for a smaller num-

11 Nilsson (2010), 86-92; Nilsson (2008), 120-123; Ingrid Lindell, Disciplinering och yrkesutbildning: Reformarbetet bakom 1918 års praktiska ungdomsskolereform (Stockholm: Stockholms universitet, 1993), 35, 38-40.

12 Lars Pettersson, "Därför valde Sverige en annan väg än Danmark," in Håkansson and Nilsson, ed., (2013), 155-167, 178-181; Michael Dobbins and Marius R. Busemeyer, "Socio-Economic Institutions, Organized Interests and Partisan Politics: The Development of Vocational Education in Denmark and Sweden," Socio-Economic Review 13, no. 2 (2015), 269-70, 276-77. For further discussion of the importance of the size of firms in relation to different institutions of vocational education and training see: Pepper D. Culpepper, "Small States and Skill Specificity: Austria, Switzerland, and Interemployer Cleavages in Coordinated Capitalism," Comparative Political Studies 40, no. 6 (2007). 
ber of students. They were precursors to the full-time schools that began to dominate Swedish skill formation in the 1950s and 1960s, but such school dominance was neither the intention nor the immediate outcome of the reforms. Nilsson states that the 1918 reform can be seen as half of a German system, with the other half, an apprentice law, missing. But the interwar period is hard to categorise. Since the $1950 \mathrm{~s}$ Sweden has been seen as 'statist', like France. ${ }^{13}$ It is clear that regarding the vocational schools a broad coalition, capable of driving institutional change, was formed. Why then was there no coalition for the other side of skill formation, that is, apprentice training?

As evident from above, existing research has largely focused conflicts and opposition to apprentice legislation, but is this the full picture? From 1924 and onwards, industry employers and unions did oppose legislation, but was this true pre-1920? And was Sweden in 1890-1917 already dominated by large, mass-producing, lowskill industrial enterprises in general and their employer organisation, Svenska arbetsgifvareföreningen (SAF), in particular? Here, the views vary and it is useful to apply Thelen's distinction between knowledge-intensive sectors (new and old) such as crafts and mechanical engineering (most of it, at least), and less skill-dependent industries such as sawmills, textiles and paper mills. Moreover, SAF was only one of several key employer organisations. ${ }^{14}$

\section{Theoretical framework and the Swedish case in a European perspective}

In a European perspective this study adds a case study of training in a country in which apprenticeship was still, but later ceased to be, the dominant form of skill formation in manufacturing. Much attention has been devoted to cases of 'collective' systems such as Denmark and Germany, where apprenticeship remained dominant. These states introduced new laws around the time period of this study. Most countries lacking apprentice laws did not develop collective systems, and have received less attention; training in particular in such countries is less researched compared to vocational schools. The Swedish case will contribute to the understanding of the requirements for an apprentice law and illustrate some institutions, which developed in its place. ${ }^{15}$

Sweden is also an interesting case against the background of research that has emphasised path dependency. The often utilised ideal types of Germany's dual system, combining apprenticeship with vocational schools, Great Britain's liberal system

13 Lindell (1993), 35-36, 46, 71-72, 211-12, 214-28; Anders Hedman, I nationens och det praktiska livets tjänst: Det svenska yrkesskolesystemets tillkomst och utveckling 1918 till 1940 (Umeå: Umeå universitet, 2001), 40, 54-55, 241-44; Olofsson (2005), 43-45, 51, 54-55, 238-40; Nilsson (2010), 90-95.

14 Hedman (2001), 41, 246; Dobbins and Busemeyer (2015), 269-70, 276-77; Lennart Erixon, The Golden Age of the Swedish Model: The Coherence between Capital Accumulation and Economic Policy in Sweden in the Early Postwar Period (Stockholm: Stockholm University, Department of Economics, 1997), 18; Lars Magnusson, An Economic History of Sweden (London: Routledge, 2000), 12123, 138; Tom Ericsson, Mellan kapital och arbete: Småborgerligheten i Sverige 1850-1914 (Umeå: Umeå universitet, 1988), 14-15, 20, 74-77, 169-70. Anders Kjellberg, "Arbetsgivarstrategier i Sverige under 100 år", in Arbejdsgivere $i$ Norden: En sociologisk analyse af arbejdsgiverorganiseringen $i$ Norge, Sverige, Finland og Danmark, ed. Carsten Strøby Jensen and Anders Kjellberg (København: Nordisk Ministerråd, 2001), 164-66.

15 Marius R. Busemeyer and Christine Trampusch, ed., The Comparative Political Economy of Collective Skill Formation (Oxford: Oxford University Press, 2012), 164-66, 168-69. 
with little state involvement, and France's statist, school-based system are thought to be heavily path-dependent. In that regard, Sweden's lack of path dependency stands out. $^{16}$

In the previous international research on different skill systems, a frequently used framework is that of varieties of capitalism $(\mathrm{VoC})$. It connects institutions of vocational education and training to a broader set of complementary institutions that together constitutes a particular type of capitalist society. Strong apprenticeship is, for example, often combined with strong employer organisations and unions, extensive social insurance systems and long-term financial arrangements. This type of society is called a CME, a coordinated market economy. The other main variety of capitalism is called a liberal market economy, a LME, and is characterised by a heavier dependence on markets. Usually apprenticeship is weak in LMEs. Sweden is considered to be a CME, but is not characterised by strong apprenticeship. Hence, from a VoC standpoint it is interesting to pose the question of why Sweden did not get an apprentice law. ${ }^{17}$

The theoretical framework of this article is Thelen's model of the emergence of institutions supporting apprenticeship. Thelen argues that the regulation of training needs to be supported by political coalitions between two or more actors, such as employer organisations, labour unions and the state. Actors in knowledge-intensive sectors of the economy are more likely to be interested in training than actors in less skill-intensive sectors. Coalitions between actors are a requirement for comprehensive regulation and regulation, in turn, is necessary for the survival of strong apprenticeship. Thelen, independently and with the political scientist Pepper D. Culpepper, has also identified class conflict as particularly detrimental to apprenticeship. Furthermore, state actions in the late nineteenth and early twentieth century play an important role in their analysis, especially in those cases where the employers are divided on the issue of apprenticeship. The state treatment of the craft sector, the traditional arena for apprentice training, is key. In Germany, the state chose to favour the craft employers rather than the industry employers, as a way to stem class conflict brought on by industrialisation. The state allowed the craft guilds to remain in voluntary form, preserving an organisational platform for the craft employers. An apprentice law for the crafts was passed in 1897 and chambers of craft employers (of all trades) were given parapublic authority to oversee skill certification. Training became contested between crafts and industry due to the actions of the state. In contrast, in Great Britain the guilds were dissolved by the state, weakening the craft employers. The craft workers on the other hand formed strong trade-based craft un-

16 Wolf-Dietrich Greinert, Mass Vocational Education and Training in Europe: Classical Models of the 19th Century and Training in England, France and Germany during the First Half of the 20th (Luxembourg: Office for Official Publications of the European Communities, 2005); Torben Iversen and John D. Stephens, "Partisans Politics, the Welfare State, and Three Worlds of Human Capital Formation," Comparative Political Studies 40, no. 4/5, (2008); David Ashton, Johnny Sung and Jill Turbin, "Towards a Framework for Comparative Analysis of National Systems of Skill Formation," International Journal of Training and Development 4, no. 1, (2000), 8-25.

17 Peter A. Hall and David Soskice, "An Introduction to Varieties of Capitalism," in Varieties of Capitalism: The Institutional Foundations of Comparative Advantage, ed. Peter Hall and David Soskice (Oxford: Oxford University Press, 2001), 9-12, 18, 25-27; Marius R. Busemeyer and Janis Vossiek, "Global Convergence or Path Dependency? Skill Formation Regimes in the Globalized Economy," in The Handbook of Global Education Policy, ed. Karen Mundy et al. (Hoboken: John Wiley and Sons, 2016), 147-49; Culpepper (2007), 612-14, 631; Thelen (2004), 2-4. 
ions and tried to control the supply of skilled labour by controlling training, which the employers strongly opposed. Class conflict was a fact, with training contested between unions and employers, and there was no legal regulation of apprenticeship. Eventually the employers defeated the union control of training and centralised collective bargaining grew influential, but the employers refused to include apprenticeship in the central agreements. ${ }^{18}$

The analysis in this article of why Sweden did not get an apprentice law between 1890 and 1917 is inspired by Thelen's research. Accordingly, I will pay special attention to the key factors identified by Thelen, that is, state treatment of the craft sector in the late nineteenth and early twentieth century, the positions on regulation of training of employers and unions in skill-dependent and less skill-dependent sectors of the economy and whether or not there was class conflict over apprenticeship. In doing so an atypical case will be added to the international research into vocational education and training systems.

\section{The actors}

The actors that had an impact on the issue of apprenticeships in Sweden between 1890 and 1917 were the employer organisations of the crafts, mechanical engineering and large, industrial companies as well as the labour unions and the state.

The craft employers' voluntary associations grew into a national organisation of both craft associations and trade-based employer organisations. In 1905, the organisation split into two. Centrala arbetsgifvareförbundet (CA) became the employer organisation and the labour market party of the building trades and crafts. Sveriges handtverksorganisation ( $\mathrm{SHO}$ ) housed the craft associations and was to promote the general craft interests, such as skill formation, but still consisted only of employers. In 1910, industry employers created a similar organisation, Sveriges industriförbund. Sveriges arbetsgifvareförening (SAF), representing employers in large-scale industry, was formed in 1902. The same year, the employers within mechanical engineering formed Sveriges verkstadsförening (VF). Perhaps the fragmentation of the employer organisations was due to different strategies. Both SAF and VF, representing largescale industry employers and mechanical engineering employers, saw the limited resources of the small firms as a liability to mutual strike insurance (an early SAF strategy) and lockouts. The small craft employers in CA, on the other hand, did not want strike insurance and were in general less aggressive towards the unions. ${ }^{19}$

The unions were less fragmented. A national, peak-level organisation of the unions, Landsorganisationen (LO), was formed in 1898. In 1907 the unionisation level was about $30 \%$, but after the 1909 general strike it took LO ten years to recuperate in terms of members and strike funds. Skilled craft workers formed trade-based unions in the late 1800s, and in the early 1900s unskilled workers followed suit. In 1912, LO argued that the unions ought to be industry-based rather than trade-based, with all the employees of a firm in the same union, to increase their clout and unity, but between 1890 and 1917 the unions were mainly trade-based, especially in the crafts. ${ }^{20}$

18 Culpepper and Thelen (2008), 25-26, 29, 43; Thelen (2004), xi, 20-23, 39-47, 92-93, 100-2, 109$10,145-47$.

19 Söderberg (1965), 172-224; Kjellberg (2001), 164-66, 170.

20 Lundh (2010), 88-98. 


\section{Parliament in 1895 - three camps}

In 1895, when two members of the second chamber of the Swedish parliament (MPs) presented, on behalf of the craft employers, a motion on an apprentice law for the crafts, the positions of the Swedish politicians can be divided into three camps. The first camp consisted of those MPs who sought a strict apprentice law in line with the wishes of the craft employers. The second camp of MPs agreed that there was a need for an apprentice law, but sought a looser, less coercive form of legislation; a parliamentary committee that processed the motion ahead of the debate also belonged to this camp. The third camp did not want any legal regulation of training and saw the free mutual agreement as a sufficient means of organising apprenticeship.

The opinions of the first camp can be found in the 1895 motion, which also included an 1893 craft employer draft of a law. ${ }^{21}$ This $1893 \mathrm{draft}$, and the 1895 motion, called for an official enquiry into an apprentice law with mandatory contracts and tests, certification by craft associations and a five-year maximum indenture, but no ban on using apprentices for tasks outside of the trade. The local craft associations tried to influence the outcome of the debate by sending letters to their local MPs in support of the motion. Several such letters were mentioned or read out loud in the parliamentary debate. ${ }^{22}$

However, the matter is further complicated by the fact that when one of the co-authors, Andersson from Malmö, ${ }^{23}$ presented the motion in parliament, he softened the demands in the face of earlier criticism. He argued that the enquiry could decide on a suitable maximum indenture instead of the five-year maximum requested in the motion and the tests did not have to be mandatory; instead, the voluntary tests could be strengthened. Andersson's new version became the rallying point of the motion-friendly MPs in the 1895 parliamentary debate. They talked of apprentices running away, bad training and inactive, unsupervised youths and argued that their type of law would control the abuses of both the employer and the apprentice and create better incentives, thereby increasing skills and upholding the crafts in competition with industry. ${ }^{24}$

The second camp consisted of a parliamentary committee and a set of like-minded members of parliament. The parliamentary committee agreed that an enquiry into regulation of the rights and responsibilities of the employer and apprentice was needed, but countered with an outline of a more limited law. This limited law was to encourage examination through a legal framework, but the committee did not want more than three years of indenture and they were deeply opposed to mandatory tests, fearing a slippery slope towards skill-based licensing for all craft employers, like the guild system. The committee wanted a Danish system with widely used voluntary tests, and a ban on using apprentices for tasks outside of the trade had to be included. This proposal passed (having narrowly avoided outright rejection). The first chamber of parliament then approved the decision from the second chamber

21 Overall, the 1895 motion in parliament is in line with the content of the 1893 craft employer draft, hence they are treated together here.

22 Motion, 2nd chamber, 1895, no. 164. Minutes, 2 nd chamber, 1895 no. 26, 41, 45-47, 49-50, 54-56; Minutes, 2nd chamber, 1895, no. 27, 1-3, 6, 9, 11, 13-14, 20.

23 Co-author with Larsson, Uppsala.

24 Minutes, 2nd chamber, 1895, no. 26, 41-47, 49-51, 54-56; Minutes, 2nd chamber, 1895, no. 27, 1, $5-6,11-15,20,30-32$. 
without debate. The subsequent official enquiry was assigned the task of drafting a law that encouraged tests without impairing freedom of trade. ${ }^{25}$

The third camp of MPs in the second chamber of parliament deemed even the position of the parliamentary committee to be too invasive. Instead this camp preferred the free mutual agreement, combined with the existing employment law. This law recognised voluntary apprentice contracts (three years maximum) and included a ban on using workers for tasks outside of the trade. All workers were supposed to be able to attend trade schools, though the impact of this regulation was limited. There was no guarantee of on-the-job training. However, actual agreements, even on the length of indenture, were rare and the three-year maximum was ignored; most trades had four years of training. Still, many MPs were pleased with the status quo. They thought that the skill level was high enough and that the law would only increase the employers' misuse of apprentices. The free agreement - "det fria aftalet" 26 - was their leitmotif. Increased coercion would discourage youths from joining the crafts and drive them to the factories; it was best to mimic the liberal labour markets of Great Britain and the United States. Interestingly, this opinion was strong in parliament, but marginalised among employer and worker organisations in the consultations. However, Hahn, one of these MPs, later became chairman of a craft association, indicating disagreement among the craft employers. ${ }^{27}$

\section{The first enquiry - union opposition}

As a first step, following the 1895 parliamentary decision to perform an official enquiry into apprentice legislation, the government chose to conduct a consultation on the motion of 1895 (including the 1893 craft employer draft) and the parliamentary committee's statement of 1895 . In this case, unlike the later ones, the consultation preceded the enquiry. In the 1900 report that summarised the replies, the main questions was whether or not different organisations thought there was a need for legal regulation of apprenticeship within the crafts or not. And, if so, which specific regulations might be called for to structure apprentice training. Among the replies there was a dividing line between employers and workers, 50 employer organisations, 40 employers and three unions supported the idea of an apprentice law, while 67 unions opposed it. However, it is noteworthy that the unions had partially been consulted on the 1893 draft that reflected the employers' interests. ${ }^{28}$

Nearly all proponents of apprentice legislation, that is, for the most part, the employers, wanted regulations in line with the $1893 \mathrm{craft}$ draft, such as mandatory contracts of a maximum of five years. There was disagreement on mandatory tests, but

25 Minutes, 2nd chamber, 1895 no. 26, 46, 51-54; Minutes, 2nd chamber, 1895 no. 27, 1-3, 8-9, 11, 12, 18-20, 24-25; 2nd chamber, 1895, temporary committee no. 4, statement no. 15; Minutes, 1st chamber, 1895 no. 33, 55.

26 Minutes, 2nd chamber, 1895 no. 27, 8, 12, 24.

27 Minutes, 2nd chamber, 1895 no. 27, 3-9, 12, 15-18, 20-30, 33-34; 2nd chamber, 1895, temporary committee no. 4, statement no. 15, 10-11; Förslag till lag om vissa lärlingsaftal (Stockholm: Isaac Marcus' boktryckeri-aktiebolag, 1909), 73; "Hahn, släkter," Svenskt biografiskt lexikon, 760-61. See also: Lundh (2010), 61-62.

28 Lärlingsfrågan inför regeringen (1900), 3-6; Söderberg (1965), 174, 178-80, 204; Centralstyrelsen för Sveriges handtverks-och industriföreningar, Årsberättelse och protokoll med bilagor (Stockholm: Andréns boktryckeri-aktiebolag, 1896), 9-10. See also: Förslag till lag om vissa lärlingsaftal (1909), 50-53. 
some of it was illusory, as those who favoured voluntary tests did so because they were seen as more politically viable. Some wanted the test to be a requirement, a license, for all craft firms (to be fulfilled by the employer or an employee). The mandatory tests were seen as an incentive to learn and verified both the apprentice's skill and the employer's training. ${ }^{29}$

The opponents to legal regulation of apprenticeship, the 67 unions, saw legislation as unnecessary, even harmful, and unable to raise the skill level or uphold the crafts. The most outspoken opponent, a trade union from Gothenburg, Göteborgs arbetareförening, argued that it would even harm the craft employers in the competition with industry, while also subjecting them to costly obligations. Furthermore, legislation was likely to have a negative impact on the workers, according to Göteborgs arbetareförening. Erring employers probably would not be punished. Instead, vocational schools ought to be combined with skills acquired just by working. Many unions agreed, but had further concerns; apprentices could be used as strike breakers and employers might hire too many apprentices. If there was a law, they wanted regulation of the ratio of apprentices to skilled workers. Lastly, many unions opposed extending the indenture, as the increasing specialisation within the craft trades ought to lead to shorter training periods rather than longer ones. ${ }^{30}$

After the consultation a committee from the Board of Trade and Commerce (Kommerskollegium), a state agency, summarised the results in a 1900 report and outlined a law. The committee argued that a law was needed for the advancement of skill and for upholding the crafts. Current skill formation was insufficient. The committee wanted mandatory contracts, a five-year maximum indenture and a ban on poaching apprentices. They proposed voluntary tests, but the majority of the committee from the Board of Trade and Commerce wanted the test to be a criterion for at least the right to train apprentices or, preferably, to run a craft firm - just the type of licensing parliament wanted to avoid. The committee argued that freedom of trade was still guaranteed, as unlicensed employers could employ licensed workers. New state agencies would oversee the tests. Craft associations, but not unions, could elect members to the new agencies. To guard against employer misuse, the committee from the Board of Trade and Commerce wanted to limit the number of apprentices per employer and to ban using apprentices for tasks outside of the trade. The test was seen as a way to check the quality of the training. An employer who had broken contracts twice would lose the right to train apprentices. ${ }^{31}$

Two members of the committee from the Board of Trade and Commerce argued, in a reservation, that the majority had gone too far - the proposal did impair freedom of trade. Furthermore, the employers just wanted cheap labour and would not submit to the responsibilities and it was apparent that the law went against the workers' interests from their many objections. The authors of the reservation saw vocational schools as a more modern approach. ${ }^{32}$

29 Lärlingsfrågan inför regeringen (1900), 4-6.

30 Lärlingsfrågan inför regeringen (1900), 6-7; Söderberg (1965), 204; Tage Lindbom, Den svenska fackföreningsrörelsens uppkomst och tidigare historia 1872-1900 (Stockholm: Tiden, 1938), 323-27.

31 Lärlingsfrågan inför regeringen (1900), 13-27; Söderberg (1965), 204.

32 Lärlingsfrågan inför regeringen (1900), 27-28. The two committee members who submitted the reservation were Rehbinder and Malmén, both of them held high positions within the Board of Trade and Commerce. 
The 1900 report was never subject to consultation, but it is possible to compare the committee's outline of a law with the opinions of the actors as stated in the consultation that preceded the enquiry and with what is known of the response to the 1900 report. The proposal of 1900 matched most of the craft employers' wishes: licensing, mandatory contracts, longer maximum indenture and some influence for the craft associations. They had also been in contact with the committee from the Board of Trade and Commerce, before the 1900 report was finished, pushing for mandatory tests and licensing. However, the state did not enter into an alliance with the craft employers. It may have been that the union opposition made presenting the law in parliament politically difficult. The economic historian Christer Lundh points out that the state in Sweden was unusually neutral towards the unions and refrained from passing anti-union laws. In addition, the sociologist Anders Kjellberg argues that the Swedish political right was fragmented at this time and, for the most part, unable to pass labour market regulations. The public and the press were also relatively union-friendly. ${ }^{33}$ The support in parliament for the 1900 proposal was consequently likely to be weak, especially since the 1900 proposal for an apprentice law went far beyond the 1895 parliamentary decision.

The historian Tage Lindbom argues that the unions were, in general, positive towards apprentice regulation, but disliked the specific content of the proposal. However, it is unclear which proposal this refers to, the motion and the parliamentary statement of 1895 that were sent out in the consultation, or the 1900 report of the committee from the Board of Trade and Commerce. Lindbom states that the interests of the unions - limiting entry into the trades and preventing exploitation - had been neglected. This, in turn, implies that he is discussing the union response to the consultation materials, and perhaps, in particular, the $1893 \mathrm{craft}$ employer draft that was included therein, which did not address the key union issues. The $1893 \mathrm{craft}$ employer draft lacked both a ban on using the apprentices for tasks outside of the trade and limits on the number of apprentices per employer, for example. However, the committee's proposal of 1900 did, to a larger extent, take the union concerns into account and included both of these regulations. Circulating the $1893 \mathrm{craft} \mathrm{em}-$ ployer draft may therefore have damaged the law's chances. When the 1900 report, with its more worker-friendly regulations, was published, the union opposition was documented right next to the proposal. ${ }^{34}$

The political process described above can be interpreted in Thelen's terms: in 1900, Swedish apprentice legislation was contested between craft employers and craft unions, judging from the pattern of disagreement. The position of the industry employers is harder to determine, since their view is not included in the material. The proposal of 1900 was only for the crafts and the large industry employer organisations had not been formed in 1900. There is some indication that, in 1903 the employers in mechanical engineering (VF), were positive towards a law, but doubted its chances. ${ }^{35}$

33 "Årsberättelse," Handtverks- och industri-tidning, July 31, 1900a; "Lärlingsfrågans behandling och nuvarande ståndpunkt i Sverige samt i förening därmed betygsfrågan," Handtverks- och industri-tidning, August 3, 1900b. Though the craft employers wanted to keep control of the tests: "En lärlingslag," Handtverks- och industri-tidning, November 27, 1900c. Lundh (2010), 87-88; Kjellberg (2001), 164.

34 Lindbom (1938), 326.

35 "Lagstiftning eller ej," Handtverks- och industri-tidning, October 30, 1903. 
The craft employers pushed for implementation of the 1900 proposal, but with increasing resignation. In 1903, one board member said that the public viewed the proposal "as an expression of despicable class legislation" 36 favouring the employers. Meanwhile, Sveriges handtverksorganisation (SHO), the national organisation of craft employers, took other forms of action and managed to standardise the diplomas, medals and premiums of the tests to some degree among the local craft associations that performed the tests. However, SHO fared less well with standardisation of execution and content of the examinations. The impact of the tests remains unclear. They were becoming a marginal tradition, but Söderberg argues that numbers alone do not show their significance; the grades and rewards could spur ambition and decrease the risk of apprentices leaving ahead of time. Still, the craft employers, the 1895 parliament and the 1900 report saw them as insufficient. ${ }^{37}$

While apprentice legislation was being debated, collective bargaining agreements, sometimes with training regulations, became more common. Due to the union opposition to the law, collective bargaining seemed, to some, a more realistic way to regulate training. The minister of finance was reported to have said so in 1904. There were similar opinions among the craft employers, though most were hoping for a law. The employers in mechanical engineering, Sveriges verkstadsförening (VF), showed some interest in collective bargaining on training, but after one failed attempt in 1904-1905 they seem to have favoured one-sided employer regulations..$^{38}$

As a result, and despite the lack of progress on a political level regarding apprentice legislation, regulation of training, by a different route, that is, through collective bargaining, expanded, albeit from a very low level. By 1909, apprentice rules were found in 316 collective bargaining agreements; 199 had very limited rules, and 117 were slightly more ambitious. However, widespread systematic regulation existed only in 10 areas, all of them of craft origin. ${ }^{39}$ Still, collective bargaining had become a way to systematically regulate apprenticeship.

36 Minutes, central board, April 6 1903, A1:1, Sveriges handtverksorganisation (SHO), Riksarkivet (RA).

37 Sveriges handtverksorganisation, Handlingar vid Sveriges handtverksorganisations ordinarie årsmöte $i$ Kristianstad den 29-30 juli 1907 (Kristianstad: Föreningen nya boktryckeriet, 1907), 42-43; Minutes, annual meeting, 1905, A3:1, SHO, RA, 11-12; Minutes, annual meeting, appendix M, 1906, A3:2, SHO, RA, 13-14; Minutes, annual meeting, appendix A, T, U, 1906, A3:2, SHO, RA; Sveriges handtverksorganisation (1907), 5-7, 88; Sveriges handtverksorganisation, Handlingar vid Sveriges handtverksorganisations ordinarie årsmöte i Norrköping den 27-28 juli 1906 (Kristianstad: Föreningen nya boktryckeriet, 1906), 23-25; Söderberg (1965), 204, 268-69, 272.

38 Minutes, annual meeting, 1906, A3:2, SHO, RA, 13-14; Sveriges handtverksorganisation (1907), 6-7, 42-46; Henning Elmquist, Åtgärder för ordnande af lärlingsväsendet inom det svenska handtverket: En sammanfattande redogörelse (Kristianstad: Sveriges handtverksorganisation, 1906), 18; Handtverks- och industri-tidning (1903); Jan O. Berg, På spaning efter svensk modell: Idéer och vägval i arbetsgivarpolitiken 1897-1909 (Enebyberg: Berg Bild Rum \& Färg Förlag, 2011), 123-24, 131-34, 143. In the craft employers' view, the minister supported a law, but worried about its effectiveness: "Lagstiftning eller organisation," Handtverks- och industri-tidning, October 23, 1904a; "Cirkulär," Handtverks- och industri-tidning, January 22, 1904b; "Sveriges målaremästareförening," Handtverks- och industri-tidning, February 19, 1904c.

39 Betänkande med förslag till lag om vissa lärlingsavtal I: Allmänna grunder (Stockholm: Isaac Marcus' boktryckeri-aktiebolag, 1911), 14-15, 18; Förslag till lag om vissa lärlingsaftal (1909), 54-60. 


\section{The second enquiry - divided employers, silent unions}

In 1904 the craft employers in SHO began to call for a new draft of an apprentice law for the crafts with mandatory contracts, a skill-based license for those who trained apprentices, a ban on poaching apprentices, mandatory tests, and set forms of arbitration and sanctions. They thought it likely that the union opposition had subsided, since training was now covered in collective bargaining. Hence, they took the union support for one form of regulation (collective bargaining) as support for a completely different form of regulation (legislation). Perhaps rightly so, as Lindbom argues that the main thing for the unions was the content, not the form, of the regulation. In 1907 a new enquiry was launched, still with the caveat from the 1895 parliamentary decision - no impairing of the freedom of trade. The committee consisted of J. F. Nyström from the organisation of craft employers (SHO), the chairman of the national, peak-level trade union, Landsorganisationen (LO), Herman Lindqvist, and a lawyer. ${ }^{40}$

In 1908, the employers within mechanical engineering (VF) stated that the need for an apprentice law for industry was undeniable: there was a shortage of skilled workers, Sweden had trouble competing internationally due to its low skill level, and the unions showed insufficient interest in regulation through collective bargaining. The 1907 committee for a craft apprentice law did not heed VF's call. ${ }^{41}$

The 1907 committee presented their report on an apprentice law in 1909. The report included a complete draft of a law, which covered 53 listed craft trades. In the draft, the maximum indenture was four years and written contracts were mandatory, but the tests were voluntary. The craft association would not oversee the tests, nor retain any influence over the new state agencies (with equal representation of employers and workers) that did. Apprentices would have an explicitly stated right to unionise. The craft employer representative, Nyström, submitted a reservation on two points, one of which was a major issue - he wanted mandatory apprenticeships for young workers. In his view, all young workers in the 53 listed craft trades ought to receive training..$^{42}$ A consultation was then conducted on the 1909 draft, Nyström's reservation and the appeal from the employers within mechanical engineering for an apprentice law for industry. It was a diverse set of proposals to consider. ${ }^{43}$

The craft employers in SHO objected to many of the specific regulations of the 1909 draft; the four-year maximum indenture was considered too short, the test ought to be mandatory, the craft association ought to have more influence, the apprentices ought not to have unionisation rights, and the employers' costs if an apprentice fell

40 Sveriges handtverksorganisation (1907), 42-46, 108; Centralorganisationen för svensk industri och handtverk, Handlingar vid centralorganisationens för svensk industri och handtverk årsmöte 1905 (Stockholm: Vårt lands boktryckeri, 1905), 1-3; "Förslag till remiss av ärendena," minutes, annual meeting, appendix F, 1907, A3:3, SHO, RA; Söderberg (1965), 248; Lindbom (1938), 326.

41 "Lärlingsfrågan," Verkstäderna, December 15, 1908, 252; Kommerskollegium, Kungl. Maj:ts och rikets Kommerskollegii underdåniga utlåtande öfver det af särskildt utsedda kommitterade den 14 januari 1909 afgifna betänkande med Förslag till lag om vissa lärlingsaftal (Stockholm: Isaac Marcus boktryckeri-aktiebolag. 1910), 6; Sveriges handtverksorganisation, Handlingar vid Sveriges Handtverksorganisations 5:te ordinarie årsmöte i Stockholm den 11-12 juli 1909 (Kristianstad: Kristianstads läns tidnings A-B tryckeri, 1909), 86-87.

42 Förslag till lag om vissa lärlingsaftal (1909), 2-4, 97-98, 105, 129-31.

43 Among others, 57 craft associations, the board of SHO, VF and CA and nine unions, replied. Kommerskollegium (1910), 4. 
ill were too high. In a newspaper article, the craft employers were accused of being negative and conservative. The board of SHO defended their members, stating that one-third of the members (and the board) supported the draft (with minor changes). What was 'minor' was open to interpretation, but the draft did not receive strong support from the craft employers. Some SHO members supported expanding the law to industry, but the board did not want an industry law to delay the craft law. The employer organisation of the building trades and crafts, Centrala arbetsgifvareförbundet (CA), mostly agreed with $\mathrm{SHO}$, but was even more critical of what they saw as too much worker influence and they supported extending the law to industry. ${ }^{44}$

The employers within mechanical engineering (VF) treated the $1909 \mathrm{draft}$ as an apprentice law for industry. VF agreed with the craft employers in SHO and CA that the four-year maximum indenture was too short, that apprentices should not have unionisation rights and that the employers' costs for sick apprentices were too high. The employers within mechanical engineering, however, wanted less, not more, regulation of examinations and even questioned the apprentices' right to voluntary tests. VF also rejected Nyström's suggestion of mandatory training. ${ }^{45}$

The national organisation of the unions (LO), did not respond. Very few labour unions did, only nine in total, most likely due to the on-going general strike. However, in 1913, LO stated that at that point they were in favour of the $1909 \mathrm{draft}$, but not the new version. The few unions who replied to the 1909 consultation were all in favour of the 1909 draft and sought very few revisions. The advancement of skill was worth the cost. However, there was a wide gap between them and the employers. The unions did not support the craft employer representative Nyström's suggestion of mandatory training. Furthermore, while the craft employers wanted a maximum indenture of five year, a few of the unions emphasised that the four-year maximum was enough. Two unions wanted guarantees for the apprentices' right to abstain from work during strikes and lockouts, while the employer organisations were against even the apprentice's right to join a union. Only the non-socialist union, Svenska arbetareförbundet, agreed with the employers' opposition to apprentice unionisation, arguing that it would force the apprentices to choose between their masters and their unions. Three unions supported expanding the law to industry, the rest ignored the question. At least one union wanted a limit on the ratio of apprentices to skilled workers. $^{46}$

In summary, the craft employers were divided internally and wanted substantial revisions. Engineering industry employers demanded a law for industry and, read in that light, the 1909 draft needed major revisions. To further complicate the picture,

44 "Styrelsen för Sveriges Handtverksorganisations yttrande öfver lärlingslagförslaget," Handtverksoch industri-tidning, July 8, 1909a, 348-53; Sveriges handtverksorganisation (1909), 75-84, 86-88; "Lärlingsfrågans ordnande," Handtverks- och industri-tidning, July 22, 1909b, 376-7.

45 Sveriges handtverksorganisation, Handlingar vid Sveriges Handtverksorganisations 6:te ordinarie årsmöte i Sundsvall den 30-31 juli 1910 (Kristianstad: Kristianstads läns tidnings A.-B. tryckeri, 1910), 86-91; Kommerskollegium (1910), 21-24, 26-27. For some earlier indications of what rules VF may have sought for training see: Handtverks- och industri-tidning (1903); "Verkstadsföreningens förhandlingsordning," Handtverks- och industri-tidning, September 22, 1905.

46 Preserved summaries from four unions: Compilation of statements on the 1909 draft, FIaa 919, Kommerskollegium (KK), RA; Kommerskollegium (1910), 4, 21-23, 30; "Utlåtande över av därtill utsedda kommitterade utarbetat förslag till lag om lärlingsväsendet i vissa yrken, Landsorganisationen i Sverige," received January 10, 1914, FI aa:919, KK, RA, 1-9. 
the revisions that the engineering industry employers sought were not in line with those proposed by the craft employers. The content of the law was, in Thelen's terms, contested between the crafts and industry. From what little we know the unions were mainly positive. The material warrants caution, but it seems that the roles were reversed in comparison to the 1900 report. Then, the craft employers supported the draft, but the unions opposed it. Now, the employers were divided, and opposed much of the 1909 draft, while the unions favoured it. It seems then, that there was an element of class conflict over the content of apprentice legislation. Clearly, there was no unified support behind the 1909 draft, but almost all of the replies deemed a law to be necessary, even if they did not support the specifics. ${ }^{47}$ There was agreement on the need for a law, but strong disagreement on the content.

In 1910 the Board of Trade and Commerce summarised the consultation and, based on that, suggested revisions generally in line with the wishes of the craft employers in SHO, such as a five-year maximum indenture, stronger rules against poaching and a removal of the question of unionisation from the law. They also agreed with SHO that a law for industry ought not to delay the craft law. Unlike SHO, the Board for Trade and Commerce suggested voluntary tests and saw the employers' responsibilities for sick apprentices as reasonable. ${ }^{48}$ At that point, however, the work on an apprentice law for only the crafts ceased and attention turned towards a combined law for both the crafts and industry.

\section{The third enquiry - mostly criticism}

The request from the employers in mechanical engineering (VF) for an industry apprentice law bore fruit and led to an enquiry into a combined craft and industry law. Major changes in the 1913 draft of an apprentice law, compared to the 1909 draft included mandatory training for young workers (with extensive exceptions), mandatory tests and a long trial period. Instead of a list of trades, the law would cover any manufacturing trade where a minimum of two years of training was needed (with a maximum of four years). The apprentice was to be allowed to be absent for no more than five days in a row without leave or due cause. The right to unionise was not explicit. ${ }^{49}$

All employer organisations wanted revisions. The craft employers in SHO felt the draft aligned more with the interests of industry and sought stricter rules, fewer exceptions to the mandatory training and a shorter trial period. The craft employers also emphasised the importance of the anticipated vocational schools. Söderberg claims that the schools by now were more important to SHO than the apprentice law, but there is not much evidence to support that. SHO still wanted a law, just not this one. The large, industrial employers in Svenska arbetsgifvareföreningen (SAF) and the craft employers in CA (in a joint statement with other employer organisations), were, surprisingly, in favour of mandatory tests and did not object to mandatory apprenticeship for young workers. This stands in sharp contrast to the later position of SAF, as an avid opponent of apprentice legislation, in the 1920s. Regarding the

47 Kommerskollegium (1910), 5.

48 Kommerskollegium (1910), 7-9, 22-23; Sveriges handtverksorganisations (1910), 75.

49 Förslag till lag om lärlingsväsendet $i$ vissa yrken (Stockholm: Isaac Marcus' boktryckeri-aktiebolag, 1913), 5-6, 9-10, 16. 
1913 draft, the employers within mechanical engineering (VF) were more critical than SAF and rejected both mandatory training and tests. The industry employers in Sveriges industriförbund approved of mandatory training, but not of mandatory tests. The major employer organisations all agreed that the obligations of the employers were too costly, that the employers' rights ought to be more extensive and that five days absence was unacceptable, but they also agreed on the need for legislation..$^{50}$

The secretariat of LO, the national organisation of the unions, was very negative and saw hidden industry employer motives behind the rules, arguing that the industry employers just wanted access to cheap labour. LO sought a return to the 1909 draft, covering only the crafts. A social democrat, in a reply to the consultation, also saw the expansion to industry as a way for industry employers to hijack the law for purposes other than skill formation. However, one member of the secretariat of LO submitted a reservation against this very negative view of an apprentice law for industry and argued that an apprentice law was needed for both the crafts and industry. ${ }^{51}$

Despite the criticism in the consultation on the $1913 \mathrm{draft}$, the work on revising the proposal did not officially cease, within the Board of Trade and Commerce the work continued. The unions were seen as the main opponents and the aim of the revision was to appease them, which required limiting the law to the crafts. The work was delayed and a different official enquiry on apprentice legislation, brought on by the vocational school reforms, was launched before the revision of the $1913 \mathrm{draft}$ was finished. And so, the idea of an apprentice law was not abandoned at this point, but later enquiries into legal regulation of apprenticeship were brought on by the changed circumstances created by the existence of a national system of vocational schools that were supposed to complement apprentice training. For the schools, the unregulated training posed a problem that the new enquiry was meant to fix. However, none of the later enquiries led to legal regulation of apprenticeship either. ${ }^{52}$

While the 1913 attempt at achieving legal regulation of apprenticeship failed, a more modest form of institutional change succeeded. In 1918, the state, prompted by the craft employers in SHO, started to support (some) training financially, initially 50 apprentices per year. The state also gave support for rewards for skilled apprentices and instituted state premiums for the same purpose. SHO and its members, imbued with (very limited) parapublic authority, oversaw and co-managed parts of these new institutions. Unlike apprentice legislation, the limited state support does not appear to have been controversial. ${ }^{53}$

50 Yttrande av Styrelsen för Sveriges handtverksorganisation över förslaget till lag om lärlingsväsendet i vissa yrken, Sveriges handtverksorganisation, 1914, FIaa:921, KK, RA; Söderberg (1965), 248-49, 332; Yttrande från Svenska arbetsgifvareföreningarnas förtroenderåd, February 25, 1914, FIaa:921, KK, RA; Sveriges verkstadsförenings utlåtande öfver förslaget till lag om vissa lärlingsaftal af år 1913, January 22, 1914, FIaa:921, KK, RA; Nilsson (2010), 91.

51 Utlåtande över av därtill utsedda kommitterade utarbetat förslag till lag om lärlingsväsendet i vissa yrken, Landsorganisationen i Sverige, January 10, 1914, FIaa:921, KK, RA, 1-9a-e; Förslag till lärlingslag, Östen Undén, October, 1913, FI aa:921, KK, RA.

52 P.M. angående behandlingen av 1913 års förslag till lärlingslag inom Kommerskollegium och Socialstyrelsen, October 26, 1921, FI aa:921; SOU 1924:41, Utredning med förslag till lag om lärlingsväsendet i vissa yrken: Avgivet av Kommerskollegium och Skolöverstyrelsen (Stockholm: Kungl. Boktryckeriet \& P. A. Norstedt \& Söner), 9-13.

53 Government bill, no. 206, 1917; Parliamentary communication, no. 7, 1917, 20; Carl Ljunggren, Hantverkets stora problem (Stockholm: Norstedt, 1922), 63. 


\section{Conclusions}

The picture that emerges from previous research into the turn of the twentieth century history of Swedish vocational training is one of relatively continuous opposition to legal regulation of apprenticeship from industry employers and trade unions. The craft employers have been seen as the only supporters of apprentice legislation. This has so far been the answer to the question of why Sweden, unlike many other European countries, did not get an apprentice law in the late nineteenth or early twentieth century. The results of this investigation into agreement and disagreement in the political demands of the key actors add nuances to that picture in several ways.

My investigation has shown that, during the investigated period, the actors to a large degree agreed that there was a need for legal regulation of apprenticeship. One clear exception to this general agreement on the need for apprentice legislation was a relatively large minority of the 1895 MPs, who saw the 1890 ' institutions of apprenticeship (voluntary tests and the free mutual agreement), as sufficient to regulate training. However, the majority of the MPs sought some form of apprentice legislation. Moreover, between 1890 and $1917 \mathrm{craft}$, employer and worker organisations in general saw a need for change and all of them, at times, saw legislation as an alternative.

However, there was strong disagreement on the content of the proposed apprentice laws. The craft employers pursued legal regulation of apprenticeship, often suggesting mandatory tests and a five-year maximum indenture. Some of the craft employers also sought mandatory training for youths and skill-based license for those who trained apprentices. Costly responsibilities and unionisation rights for apprentices were seen as unacceptable by all employer organisations.

The question of mandatory tests and training was a dividing line among the employers. The 1895 parliamentary decision was intended to encourage voluntary tests. Its caveat — not to impair freedom of trade - remained throughout. The engineering industry employers in VF agreed that the test ought to be voluntary in both 1909 and 1913. VF wanted a law, but none of the drafts pleased them. In 1913, SAF, representing large-scale industry employers, surprisingly, did not object to mandatory training or tests, though they had other objections. Industriförbundet, also representing industry employers, was in favour of mandatory training, but against mandatory tests. The craft employers in SHO were strong supporters of mandatory tests and for the most part approved of mandatory training, but that was not as important to them as the tests.

Another dividing line ran between employers and unions. Both sides showed interest in legislation, but the desired content varied widely. The unions wanted to limit entry into the trades, prevent exploitation, and ensure the right to unionise. For the most part, they also wanted the law to be limited to the crafts. On the other hand, there was agreement on mandatory contracts, sanctions against breach of contract, and that more apprentices ought to take the tests.

Unlike previous research, my investigation has shown that none of the actors involved in the political struggle over apprenticeship were avid opponents to legislation during the investigated period. This, in turn, reveals that the positions of the actors in the Swedish case have been more fluid than previously thought. For example, the employers in large-scale industry, represented by SAF, were more positively inclined toward apprentice legislation in 1913 than in the 1920s. In general, between 
1890 and 1917 the support of the actors seems to be contingent upon the content of the proposed laws, rather than any fixed opinion on the suitability of legislation as a means of regulating apprenticeship.

In a European perspective it is interesting to note that in line with Thelen's identification of key actors, employers in two knowledge-intensive sectors, crafts and mechanical engineering, both demanded legislation for their respective areas of the economy, though the rules they sought differed widely. The interest in legislation in 1913 of the employers within SAF is less expected, as they are not generally seen as representing knowledge-intensive industries to the same degree. In a sense, apprentice legislation in Sweden was contested between crafts and industry (as in Germany) as well as between employers and unions (as in Great Britain). It is clear that the class conflict, which according to Culpepper and Thelen is detrimental to regulation, was very much present in Sweden. Employers and workers never agreed on the content of the drafts and the unions mistrusted the motives of the industrial employers in particular. Three things may have hindered the chances of a law further: (1) the decision to conduct a consultation, including the 1893 craft employer draft, before the 1900 report, (2) the 1909 general strike coinciding with one consultation and (3) the Swedish state's unwillingness or inability to support a law, unless there was a pre-existing coalition. The third point is a difference compared to the German case, where the state chose to support the craft employers by passing apprentice legislation that favoured them.

When previous research has tried to categorise Sweden's system of vocational education and training according to different typologies it has either been seen as statist, like France, with a heavy dependence on vocational schools or as a rare case of shifting systems with the period up until 1918 seen as a unregulated model, like the British one. While this study has focused on the question of legal regulation of apprenticeship it has at the same time shown that this was not the only alternative on the agenda at this time and other attempts at institutional change were more successful. Collective bargaining grew and systematically regulated apprenticeship in a few trades. The expansion may have been helped by the fact that the unions did not, to any great degree, try to limit the supply of skilled labour through controlling apprenticeship and that the state took a neutral and passive stance towards the unions. This regulation through (non-central) collective bargaining is a similarity with Great Britain, while the modest state support and the limited parapublic authority of the craft associations and SHO is more in line with a very light version of the German case. Any greater similarities with Germany would have required legal regulation of apprenticeship.

Later on, the vocational schools became the distinguishing feature of Swedish skill system and in that area, a coalition was formed, resulting in the 1918 and 1921 reforms, but very few saw the schools as a substitute for apprenticeship. In fact, the 1918 reform is sometimes seen as one half of an unfulfilled German system. The inability of the actors to agree on, or tolerate, the specifics of the proposed apprentice laws hindered the development of the other half. 


\section{References}

Ashton, David, Sung, Johnny and Turbin, Jill. "Towards a Framework for Comparative Analysis of National Systems of Skill Formation." International Journal of Training and Development 4, no. 1 (2000), 8-25.

Berg, Jan O. På spaning efter svensk modell: Idéer och vägval i arbetsgivarpolitiken 1897-1909. Enebyberg: Berg Bild Rum \& Färg Förlag, 2011.

Betänkande med förslag till lag om vissa lärlingsavtal I: Allmänna grunder. Stockholm: Isaac Marcus' boktryckeri-aktiebolag, 1911.

Busemeyer, Marius R. and Christine Trampusch, eds. The Comparative Political Economy of Collective Skill Formation. Oxford: Oxford University Press, 2012.

Busemeyer, Marius R. and Janis Vossiek. "Global Convergence or Path Dependency? Skill Formation Regimes in the Globalized Economy." In The Handbook of Global Education Policy, edited by Karen Mundy, Andy Green, Bob Lingard and Antoni Verger, 145-61. Hoboken: John Wiley and sons, 2016.

Centralorganisationen för svensk industri och handtverk. Handlingar vid centralorganisationens för svensk industri och handtverk årsmöte 1905. Stockholm: Vårt lands boktryckeri, 1905.

Centralstyrelsen för Sveriges handtverks-och industriföreningar. Årsberättelse och protokoll med bilagor. Stockholm: Andréns boktryckeri-aktiebolag, 1896.

Culpepper, Pepper D. "Small States and Skill Specificity: Austria, Switzerland, and Interemployer Cleavages in Coordinated Capitalism." Comparative Political Studies 40, no. 6 (2007), 611-37.

Culpepper, Pepper D. and Thelen, Kathleen. "Institutions and Collective Actors in the Provision of Training: Historical and Cross-National Comparisons." In Skill Formation: Interdisciplinary and Cross-National Perspectives, edited by Karl U1rich Mayer and Heike Solga, 21-49. Cambridge: Cambridge University Press, 2008.

Dobbins, Micheal and Marius R. Busemeyer. "Socio-Economic Institutions, Organized Interests and Partisan Politics: The Development of Vocational Education in Denmark and Sweden." Socio-Economic Review 13, no. 2 (2015), 259-84.

Elmquist, Henning. Åtgärder för ordnande af lärlingsväsendet inom det svenska handtverket: En sammanfattande redogörelse. Kristianstad: Sveriges handtverksorganisation, 1906.

Ericsson, Tom. Mellan kapital och arbete: Småborgerligheten i Sverige 1850-1914. Umeå: Umeå universitet, 1988.

Erixon, Lennart. The Golden Age of the Swedish Model: The Coherence between Capital Accumulation and Economic Policy in Sweden in the Early Postwar Period. Stockholm: Stockholm University, Department of Economics, 1997.

Förslag till lag om lärlingsväsendet i vissa yrken. Stockholm: Isaac Marcus' boktryckeri-aktiebolag, 1913.

Förslag till lag om vissa lärlingsaftal. Stockholm: Isaac Marcus' boktryckeri-aktiebolag, 1909.

Greinert, Wolf-Dietrich. Mass Vocational Education and Training in Europe: Classical Models of the 19th Century and Training in England, France and Germany during the First Half of the 20th. Luxembourg: Office for Official Publications of the European Communities, 2005.

“Hahn, släkter." Svenskt biografiskt lexikon 17 (1967-1969), 760-61. 
Hall, Peter A. and David Soskice. "An Introduction to Varieties of Capitalism". In Varieties of Capitalism: The Institutional Foundations of Comparative Advantage, edited by Peter Hall and David Soskice, 2-69. Oxford: Oxford University Press, 2001.

Handtverks- och industri-tidning (1900a). "Årsberättelse."

Handtverks- och industri-tidning (1900b). "Lärlingsfrågans behandling och nuvarande ståndpunkt i Sverige samt i förening därmed betygsfrågan."

Handtverks- och industri-tidning (1900c). "En lärlingslag."

Handtverks- och industri-tidning (1903). "Lagstiftning eller ej."

Handtverks- och industri-tidning (1904a). "Lagstiftning eller organisation."

Handtverks- och industri-tidning (1904b). "Cirkulär."

Handtverks- och industri-tidning (1904c). "Sveriges målarmästareförening."

Handtverks- och industri-tidning (1905). "Verkstadsföreningens förhandlingsordning."

Handtverks- och industri-tidning (1909a). "Styrelsen för Sveriges Handtverksorganisations yttrande öfver lärlingslagförslaget."

Handtverks- och industri-tidning (1909b). "Lärlingsfrågans ordnande."

Hedman, Anders. I nationens och det praktiska livets tjänst: Det svenska yrkesskolesystemets tillkomst och utveckling 1918 till 1940. Umeå: Umeå universitet, 2001.

Håkansson, Peter and Anders Nilsson, eds. Yrkesutbildningens formering $i$ Sverige 1940-1975. Lund: Nordic Academic Press, 2013.

Iversen, Torben and John D. Stephens. "Partisans Politics, the Welfare State, and Three Worlds of Human Capital Formation." Comparative Political Studies 40, no. 4/5, (2008), 600-36.

Kjellberg, Anders. “Arbetsgivarstrategier i Sverige under 100 år.” In Arbejdsgivere $i$ Norden: En sociologisk analyse af arbejdsgiverorganiseringen i Norge, Sverige, Finland og Danmark, edited by Carsten Strøby Jensen and Anders Kjellberg, 161284. København: Nordisk Ministerråd, 2001.

Kommerskollegium's archive (KK), Riksarkivet (RA).

Kommerskollegium. Kungl. Maj:ts och rikets Kommerskollegii underdåniga utlåtande öfver det af särskildt utsedda kommitterade den 14 januari 1909 afgifna betänkande med Förslag till lag om vissa lärlingsaftal. Stockholm: Isaac Marcus' boktryckeri-aktiebolag, 1910.

Lindbom, Tage. Den svenska fackföreningsrörelsens uppkomst och tidigare historia 1872-1900. Stockholm: Tiden, 1938.

Lindberg, Folke. Hantverk och skråväsen under medeltid och äldre vasatid. 2nd edition. Stockholm: Prisma, 1964.

Lindell, Ingrid. Disciplinering och yrkesutbildning: Reformarbetet bakom 1918 års praktiska ungdomsskolereform. Stockholm: Stockholms universitet, 1993.

Ljunggren, Carl. Hantverkets stora problem. Stockholm: Norstedt, 1922.

Lundahl, Lisbeth. Efter svensk modell: LO, SAF och utbildningspolitiken 1944-90. Boréa: Umeå, 1997.

Lundh, Christer. Spelets regler: Institutioner och lönebildning på den svenska arbetsmarknaden 1850-2010. Stockholm: SNS förlag, 2010.

Lundh Nilsson, Fay. Lönande lärande: Teknologisk förändring, yrkesskicklighet och lön i svensk verkstadsindustri omkring 1900. Stockholm: Almqvist \& Wiksell International, 2007. 
Lärlingsfrågan inför regeringen. Stockholm: Iduns kungliga boktryckeri, 1900. Magnusson, Lars. An Economic History of Sweden. London: Routledge, 2000.

Nilsson, Anders. Yrkesutbildningen i Sverige 1850-1910. Uppsala: Föreningen för svensk undervisningshistoria, 2008.

Nilsson, Anders. "From One Model to the Other: Swedish Vocational Education and Training in the Twentieth Century." In Utbildningens sociala och kulturella historia: Meddelanden från den fïrde nordiska utbildningshistoriska konferensen, edited by Esbjörn Larsson and Johannes Westberg, 83-102. Uppsala: SEC, Uppsala University, 2010.

Olofsson, Jonas. Svensk yrkesutbildning: Vägval i internationell belysning. Stockholm: SNS förlag, 2005.

Olofsson, Jonas and Eskil Wadensjö. Lärlingsutbildning: Ett återkommande bekymmer eller en oprövad möjlighet?. Stockholm: Finansdepartementet, Regeringskansliet, 2006.

Parliamentary materials, 1895.

Parliamentary materials, 1917.

Pettersson, Lars. Är Danmark bättre än Sverige? Om dansk och svensk yrkesutbildning sedan industrialiseringen. Malmö: Øi förlag, 2006.

Pettersson, Lars. "Därför valde Sverige en annan väg än Danmark.” In Yrkesutbildningens formering $i$ Sverige 1940-1975, edited by Peter Håkansson and Anders Nilsson, 155-84. Lund: Nordic Academic Press, 2013.

SOU 1924:41. Utredning med förslag till lag om lärlingsväsendet $i$ vissa yrken: Avgivet av Kommerskollegium och Skolöverstyrelsen. Stockholm: Kungl. Boktryckeriet \& P. A. Norstedt \& Söner.

Sveriges handtverksorganisation. Handlingar vid Sveriges handtverksorganisations ordinarie årsmöte i Norrköping den 27-28 juli 1906. Kristianstad: Föreningen nya boktryckeriet, 1906.

Sveriges handtverksorganisation. Handlingar vid Sveriges handtverksorganisations ordinarie årsmöte i Kristianstad den 29-30 juli 1907. Kristianstad: Föreningen nya boktryckeriet, 1907.

Sveriges handtverksorganisation. Handlingar vid Sveriges Handtverksorganisations 5:te ordinarie årsmöte i Stockholm den 11-12 juli 1909. Kristianstad: Kristianstads läns tidnings A-B Tryckeri, 1909.

Sveriges handtverksorganisation. Handlingar vid Sveriges Handtverksorganisations 6:te ordinarie årsmöte i Sundsvall den 30-31 juli 1910. Kristianstad: Kristianstads läns tidnings A.-B. tryckeri, 1910.

Sveriges hantverksorganisation's archive (SHO), Riksarkivet (RA).

Söderberg, Tom. Hantverkarna i brytningstid: 1820-1870. Stockholm: Vasatryckeriet, 1955.

Söderberg, Tom. Hantverkarna i genombrottsskedet 1870-1920. Stockholm: Vasatryckeriet, 1965.

Thelen, Kathleen. How Institutions Evolve: The Political Economy of Skills in Germany, Britain, the United States, and Japan. Cambridge: Cambridge University Press, 2004.

Verkstäderna (1908). "Lärlingsfrågan." 